\title{
Additional records of the Schneider's Toad Duttaphrynus scaber (Anura: Bufonidae) from India, with notes on its natural history
}

\author{
Khan Ashaharraza $^{1 * \odot}$, Nirmal U. Kulkarni ${ }^{2 \oplus}$, K. P. Dinesh ${ }^{3 \oplus}$ and Abhijeet Narsinrao Dani ${ }^{4 \oplus}$ \\ ${ }^{1}$ Department of Wildlife and Biodiversity Conservation, North Orissa University, Baripada- 757003, \\ Odisha, India \\ ${ }^{2}$ Mhadei Research Centre, C/o Hiru Naik Building, Dhuler Mapusa- 403507, Goa, India \\ ${ }^{3}$ Western Regional Centre, Zoological Survey of India, Akurdi, Pune- 411044, Maharashtra India \\ ${ }^{4}$ Wild Life Awareness Research and Rescue Welfare Society, Dastur Nagar, Amravati- 444606, \\ Maharashtra, India

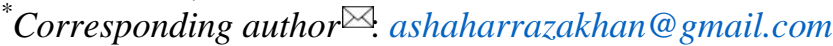

Received: 19 August 2020

Accepted: 22 November 2020

Published online: 31 December 2020

\begin{abstract}
Schneider's Toad, Duttaphrynus scaber (Schneider, 1799) is known to be distributed over the coastal peninsular, northern parts of central India and northeastern states of India. However, despite the availability of multiple published reports, there are few verified records of its occurrence from central India. Herein, we present two records of $D$. scaber, one from the Vidarbha region of Maharashtra State, central India with morphometric data, another from northern Western Ghats, from the Goa region, with morphometric, as well as molecular, data. The site selection for dormancy, sympatric species, and microhabitat preferences during the breeding season of Duttaphrynus scaber is discussed.
\end{abstract}

Key words: Geographic distribution, natural history, range extension, Vidarbha Region, India

\section{Introduction}

Duttaphrynus scaber (Schneider, 1799) was described as Bufo scaber from "Indis Orientali". The nomen Bufo fergusonii Boulenger, 1892 (type locality, Trevandrum on the Cavalry Parade Ground, Kerala, India) and Bufo stomaticus peninsularis Rao, 1920 (type locality, Mavkote and Watekille, Coorg, Karnataka, India) are currently treated as junior synonyms of Duttaphrynus scaber (Frost, 2020).

Duttaphrynus scaber is considered endemic to India and Sri Lanka (Dutta, 1997). In India, most of its distribution records in peninsular India are from Gujarat, Maharashtra, Karnataka, Kerala, Tamil Nadu, Odisha, West Bengal, (Frost, 2020). Additionally, there is a recent report from the Panna Tiger Reserve, Madhya Pradesh (Prasad et al., 2020) and another from Manipur (Mathew and Sen, 2009) in northeastern India (Frost, 2020).
The IUCN Red list of threatened species considered the conservation status of the species as Least Concern (IUCN, 2020).

Padhye et al. (2013) provided detailed information on the advertisement call pattern of Duttaphrynus scaber and its range of distribution, with genetic data. They also provided an additional record, in the form of the northernmost limit for the species in the northern Western Ghats, at Supdahad, Gujarat, India. Based on their collections, a record at Thiruvananthapuram, Kerala, India, is the southern limit and one at Manipur is the eastern limit, based on their literature survey (Padhye et al., 2013).

Problems in the identification of the species and its misidentification in peninsular India and their account details were discussed by Padhye et al. (2013); Srinivasalu et al. (2013) and Ganesh et al. (2020). 
This species can be distinguished and identified by a combination of morphological characters in having the head broader than long; less prominent cranial ridges; rounded snout; snout length less than the eye diameter; canthus rostralis not sharp; loreal region concave; interorbital space flat, less than the eye diameter; nostrils rounded, closer to tip of snout; tympanum half the eye diameter; tympanum to eye distance less than half tympanic diameter; parotid glands very prominent, round, not warty or spiny but thickened and somewhat uneven; tongue elongate; supratympanic fold absent; forelimbs moderate compared to hind limbs; finger tips round, but not dilated; subarticular tubercles prominent, double; a single prominent, rounded palmar tubercle; and palms and fingers with many tubercles (Dubois and Ohler, 1999).

During our amphibian explorations in the Western Ghats and the central Indian region, we collected some small-sized toads from multiple locations. They matched the description of D. scaber and here we report them, with their morphological details, genetic data, some aspects of natural history, and an updated map showing the distribution range for the species (Fig. 1).

\section{Material and Methods}

The collected individuals of $D$. scaber were photographed in situ using a Canon EOS Rebel T5 and a Canon SX50HS digital camera. Specimens were euthanized using MS222 (Tricaine methanesulfonate). Thigh muscle tissue samples were extracted from ZSI/WRC/A/2172 for genetic studies. After removing the tissue sample for the molecular studies, the specimens were fixed in $4 \%$ formalin solution, after 24 hours of fixation the samples were washed thoroughly in running tap water and preserved in $70 \%$ ethanol. Specimens were deposited in the National Zoological Collection of the ZSI, WRC, Pune, Maharashtra, India (ZSI/WRC/A/2172; ZSI/WRC/A/2182; ZSI/WRC/A/2240).

\section{Collection localities}

One calling male specimen of D. scaber was collected from a temporary mud pool in Chegule village, Belgaum, Karnataka, India $\left(15^{\circ} 44^{\prime} 27.59^{\prime \prime} \mathrm{N}\right.$, 74 $12^{\prime} 39.59^{\prime \prime E}$, elevation $777 \mathrm{~m}$ a.s.l.) in July, 2014 (ZSI/WRC/A/2172). One adult male of D. scaber (Fig. 2) was collected on 26 June 2017 from the backyard seasonal puddle of Gulzeb Pathan's residency, Sufiyan Nagar No. 2, Amravati, Maharashtra $\quad\left(20^{\circ} 57^{\prime} 30.96 " \mathrm{~N}, \quad 77^{\circ} 43^{\prime} 57.71\right.$ "E, elevation $331 \mathrm{~m}$ a.s.1.) (ZSI/WRC/A/2182). Two additional males were collected from Wadgaon Mahure, Amravati, Maharashtra, India (205' $15.95 " \mathrm{~N}, \quad 77^{\circ} 47^{\prime} 49.92 " \mathrm{E}$, elevation $346 \mathrm{~m}$ a.s.l.) on 13 October 2017 (ZSI/WRC/A/2182). Also, another calling male specimen was collected from the paddy fields in Tenkasi, Tamil Nadu, India
( $8^{\circ} 57^{\prime} 15.12^{\prime \prime N} ; 77^{\circ} 18^{\prime} 13.6794 " \mathrm{E}$, elevation $170 \mathrm{~m}$ a.s.l.) in August 2019 (ZSI/WRC/A/2240).

\section{Mapping}

Location data were used based on the data provided by Padhye et al. (2013), Ganesh et al., (2020), Prasad et al., (2020) and our collections from central India and the Western Ghats. The map was generated using the DIVA-GIS open source geographic information system software (Fig. 1, and Table 1).

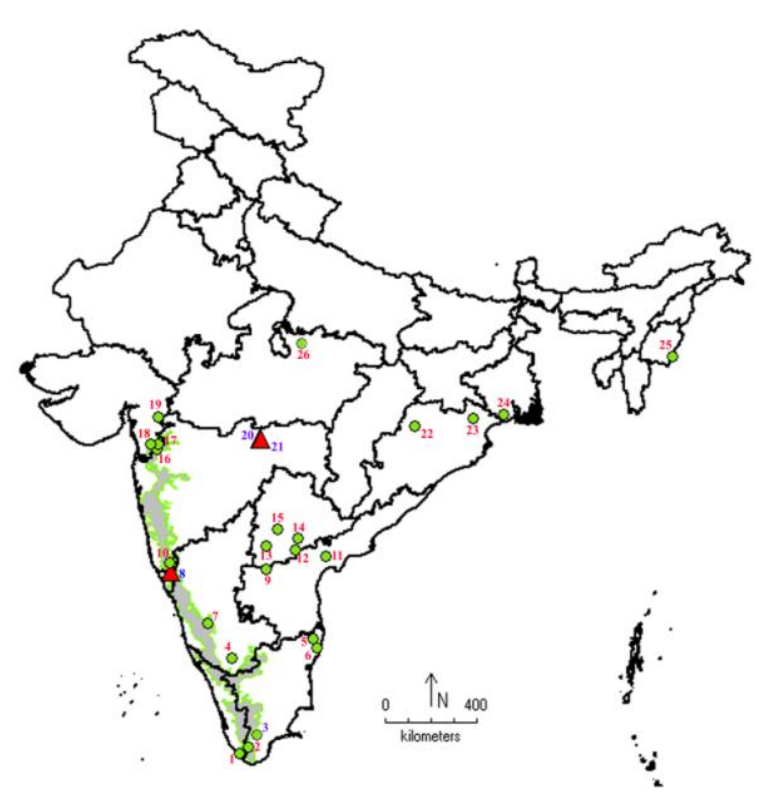

Figure 1: Map showing distribution of Duttaphrynus scaber in peninsular India (see Table 1).

\section{Phylogenetic studies}

DNA extraction, PCR amplification, sequencing and phylogenetic reconstruction protocols follow Dinesh et al. (2015). Mitochondrial 16S rRNA sequences from Padhye et al. (2013) and our sequence from Belgaum, Karnataka, India (northern Western Ghats) (see Table 2) were used.

\section{Morphological studies}

All the specimens were examined using a Leica MZ75, stereomicroscope (Leica Microsystems Ltd, Business Unit SM, CH-9435 Heerbrugg, Switzerland). Morphological measurements were measured using a Mitutoyo vernier caliper (to the nearest $0.1 \mathrm{~mm}$ ) and listed in Table 3 . The specimens were identified after Daniel (1963a, b), Dubois and Ohler (1999) and Padhye et al. (2013). Comparisons were made with materials deposited in the Collection of the Zoological Survey of India, Western Regional Centre, Pune, Maharashtra, India.

Abbreviations used for the morphometric characters are as follow: AG - axilla to groin distance; EL-eye length (horizontal distance between the bony orbital borders of the eye); FL1 - first finger length (tip of 
Table 1: Reported localities of Duttaphrynus scaber from India (Figure 1).

\begin{tabular}{|c|c|c|c|c|}
\hline No. & Collection localities & Latitude (N) & Longitude (E) & Reference details \\
\hline 1 & Trivandrum, Kerala & $8^{\circ} 30^{\prime} 35.99^{\prime \prime}$ & $76^{\circ} 57^{\prime} 0^{\prime \prime}$ & Boulenger, 1892; Daniels, 2005 \\
\hline 2 & Kalakkad, Tamil Nadu & $8^{\circ} 47^{\prime} 21.84^{\prime \prime}$ & $77^{\circ} 18^{\prime} 13.67^{\prime \prime}$ & Vijaykumar, 2002 \\
\hline 3 & Tenkasi, Tamil Nadu & $8^{\circ} 57^{\prime} 15.12^{\prime \prime}$ & $77^{\circ} 18^{\prime} 13.67^{\prime \prime}$ & new record \\
\hline 4 & Mysore, Karnataka & $12^{\circ} 18^{\prime} 36^{\prime \prime}$ & $76^{\circ} 39^{\prime} 0^{\prime \prime}$ & Daniel, 1963b \\
\hline 5 & Chengleput, Tamil Nadu & $12^{\circ} 41^{\prime} 52.8^{\prime \prime}$ & $80^{\circ} 1^{\prime} 36.83^{\prime \prime}$ & Das and Martin, 1998 \\
\hline 6 & Nungambakkam, Tamil Nadu & $13^{\circ} 3^{\prime} 59.75^{\prime \prime}$ & $79^{\circ} 53^{\prime} 39.84^{\prime \prime}$ & Rao, 1915 \\
\hline 7 & Lakkavalli, Karnataka & $13^{\circ} 42^{\prime} 3.96^{\prime \prime}$ & $75^{\circ} 39^{\prime} 21.95^{\prime \prime}$ & Krishnamurthy, 1999 \\
\hline 8 & Chegule, Belgaum, Karnataka & $15^{\circ} 44^{\prime} 25.8^{\prime \prime}$ & $74^{\circ} 12^{\prime} 41.76^{\prime \prime}$ & new record \\
\hline 9 & Kurnool, Andhra Pradesh & $15^{\circ} 49^{\prime} 48^{\prime \prime}$ & $78^{\circ} 1^{\prime} 48^{\prime \prime}$ & Srinivaslu et al., 2007 \\
\hline 10 & Kolhapur, Maharashtra & $16^{\circ} 6^{\prime} 2.98^{\prime \prime}$ & $74^{\circ} 7^{\prime} 24.95^{\prime \prime}$ & Modak et al., 2013 \\
\hline 11 & Guntur, Andhra Pradesh & $16^{\circ} 18^{\prime} 36.71^{\prime \prime}$ & $80^{\circ} 25^{\prime} 26.75^{\prime \prime}$ & Srinivaslu et al., 2007 \\
\hline 12 & Nagarjun Sagar & $16^{\circ} 34^{\prime} 21.72^{\prime \prime}$ & $79^{\circ} 12^{\prime} 0.71^{\prime \prime}$ & Srinivaslu et al., 2007 \\
\hline 13 & Mahabubnagar, Telangana & $16^{\circ} 44^{\prime} 4.92^{\prime \prime}$ & $77^{\circ} 59^{\prime} 15.72^{\prime \prime}$ & Srinivaslu et al., 2007 \\
\hline 14 & Nalgonda, Telangana & $17^{\circ} 3^{\prime} 35.99^{\prime \prime}$ & $79^{\circ} 15^{\prime} 36^{\prime \prime}$ & Srinivaslu et al., 2007 \\
\hline 15 & Hyderabad, Telangana & $17^{\circ} 24^{\prime} 39.96^{\prime \prime}$ & $78^{\circ} 26^{\prime} 49.91^{\prime \prime}$ & Donahue and Daniel, 1966 \\
\hline 16 & Nashik, Maharashtra & $20^{\circ} 33^{\prime} 33.91^{\prime \prime}$ & $73^{\circ} 38^{\prime} 2.03^{\prime \prime}$ & Padhye et al., 2013 \\
\hline 17 & Dangs, Gujarat & $20^{\circ} 45^{\prime} 19.36^{\prime \prime}$ & $73^{\circ} 41^{\prime} 0.24^{\prime \prime}$ & Padhye et al., 2013 \\
\hline 18 & Vansda, Gujarat & $20^{\circ} 45^{\prime} 43.2^{\prime \prime}$ & $73^{\circ} 22^{\prime} 0.84^{\prime \prime}$ & Harshil Patel, pers. comm., 2019 \\
\hline 19 & Shoolpaneshwar & $21^{\circ} 49^{\prime} 23.87^{\prime \prime}$ & $73^{\circ} 40^{\prime} 46.91^{\prime \prime}$ & Modak et al., 2013 \\
\hline 20 & Amravati, Maharashtra & $20^{\circ} 57^{\prime} 30.96^{\prime \prime}$ & $77^{\circ} 43^{\prime} 57.71^{\prime \prime}$ & new record \\
\hline 21 & Wadgaon Mahure, Maharashtra & $20^{\circ} 58^{\prime} 15.95^{\prime \prime}$ & $77^{\circ} 47^{\prime} 49.92^{\prime \prime}$ & new record \\
\hline 22 & Sambalpur, Odisha & $21^{\circ} 28^{\prime} 11.99^{\prime \prime}$ & $83^{\circ} 58^{\prime} 11.99^{\prime \prime}$ & Dutta, 1988 \\
\hline 23 & Mayurbhanj, Odhisa & $21^{\circ} 45^{\prime} 50.03^{\prime \prime}$ & $86^{\circ} 19^{\prime} 0.11^{\prime \prime}$ & Dutta et al., 1999 \\
\hline 24 & Purba Medinapur, West Bengal & $21^{\circ} 54^{\prime} 36.71^{\prime \prime}$ & $87^{\circ} 32^{\prime} 26.88^{\prime \prime}$ & Mahapatra and Ghorai, 2019 \\
\hline 25 & Moreh, Maipur & $24^{\circ} 15^{\prime} 13.67^{\prime \prime}$ & $94^{\circ} 17^{\prime} 46.68^{\prime \prime}$ & Mathew and Sen, 2009 \\
\hline 26 & Panna National Park, Madhya Pradesh & $24^{\circ} 44^{\prime} 3.48^{\prime \prime}$ & $80^{\circ} 00^{\prime} 52.99^{\prime \prime}$ & Prasad et al., 2020 \\
\hline
\end{tabular}

Table. 2: Details of sequences used in the phylogenetic analysis (Figure 3).

\begin{tabular}{|c|c|c|c|c|}
\hline $\begin{array}{l}\text { Species considered in the } \\
\text { present study }\end{array}$ & $\begin{array}{l}\text { Accession } \\
\text { number }\end{array}$ & $\begin{array}{l}\text { Locality as per } \\
\text { GenBank }\end{array}$ & $\begin{array}{l}\text { Species name as per } \\
\text { GenBank }\end{array}$ & $\begin{array}{l}\text { Reference as per } \\
\text { GenBank } \\
\end{array}$ \\
\hline Duttaphrynus scaber & AB530643.1 & $\begin{array}{l}\text { Mudigere, } \\
\text { Chickkamagaluru, } \\
\text { Karnataka, India }\end{array}$ & Duttaphrynus scaber & Hasan et al., 2014 \\
\hline Duttaphrynus scaber & MW052562.1 & $\begin{array}{l}\text { Chegule, } \\
\text { Belgaum, } \\
\text { Karnataka, India }\end{array}$ & Duttaphrynus scaber & Present study \\
\hline Duttaphrynus scaber & JQ898086.1 & India & Duttaphrynus scaber & Padhye et al., 2013 \\
\hline Duttaphrynus scaber & EU071741.1 & India & Bufo scaber & Unpublished \\
\hline Duttaphrynus scaber & AB530644.1 & $\begin{array}{l}\text { Mudigere, } \\
\text { Chickkamagaluru, } \\
\text { Karnataka, India }\end{array}$ & Duttaphrynus scaber & Hasan et al., 2014 \\
\hline Duttaphrynus scaber & KT991343.1 & India & Duttaphrynus scaber & $\begin{array}{l}\text { Chandramouli et al., } \\
2016\end{array}$ \\
\hline Duttaphrynus parietalis & FJ882784.1 & Not Available & Duttaphrynus parietalis & Bocxlaer, et al., 2009 \\
\hline Duttaphrynus melanostictus & EU071753.1 & India & Bufo melanostictus & Unpublished \\
\hline Duttaphrynus melanostictus & EU071759.1 & India & Bufo melanostictus & Unpublished \\
\hline Duttaphrynus brevirostris & FJ882786.1 & Not Available & Duttaphrynus brevirostris & Bocxlaer et al., 2009 \\
\hline Duttaphrynus hololius & FJ882781.1 & Not Available & Duttaphrynus hololius & Bocxlaer et al., 2009 \\
\hline Duttaphrynus stomaticus & КT991344.1 & India & Duttaphrynus stomaticus & $\begin{array}{l}\text { Chandramouli et al., } \\
2016\end{array}$ \\
\hline Duttaphrynus stomaticus & KY000461.1 & Not Available & Duttaphrynus stomaticus & Unpublished \\
\hline Duttaphrynus stomaticus & KY000458.1 & Not Available & Duttaphrynus stomaticus & Unpublished \\
\hline Duttaphrynus stomaticus & KY000460.1 & Not Available & Duttaphrynus stomaticus & Unpublished \\
\hline Duttaphrynus stomaticus & KY000457.1 & Not Available & Duttaphrynus stomaticus & Unpublished \\
\hline Duttaphrynus stomaticus & AY028500.2 & Not Available & Duttaphrynus stomaticus & Pramuk et al., 2001 \\
\hline
\end{tabular}

finger to proximal palmar tubercle); FL2 - second finger length (tip of finger to proximal palmar tubercle); FLL - forelimb length (elbow to the base of the outer palmar tubercle); FOL-foot length (base of the inner metatarsal tubercle to the tip of the fourth toe); FTL - fourth toe length (base of proximalsub articular tubercle to toe tip); HALhand length (base of the outer palmar tubercle to the 
tip of the third finger); HL-head length (rear of the mandible to the tip of the snout); HW-head width, at the angle of the jaws; IBE-distance between posterior corner of eyes; IFE-distance between anterior corner of eyes; IMT-length of inner metatarsal tubercle; IN-internarial distance; ITLinner toe length; IUE - inter upper eyelid width (shortest distance between the upper eyelids); MBE-distance from the rear of the mandible to the posterior most orbital border; MFE-distance from the rear of the mandible to the anterior most orbital border; $\mathrm{MN}$ - distance from the rear of the mandible to the centre of the nostril; NE-nostril to eye distance; NS-nostril to snout tip distance; ShL/FL - thigh length; SL-snout length (tip of the snout to the anterior most orbital border); SVLsnout to vent length; Tal-tarsus length; TEtympanum to posterior corner of eye distance; TFLthird finger length (tip of finger to proximal palmar tubercle); TiL-tibia length; TYD-tympanum diameter; UEW-maximum upper eyelid width; WBS - body width behind shoulders; WFG - body width in front of groin. AGCZRL-Abasaheb Garware College Zoology Research Laboratory; ZSI/WRC/A- Zoological Survey of India, Western Regional Centre, Pune.

\section{Results and Discussions}

In the phylogenetic analysis, our mt 16s rRNA sequences for D. scaber from Belgaum, Karnataka forms a monophyletic clade with the other sequences for the species (Fig. 3). Our sequences from Belgaum, Karnataka were homologous with the sequence AB530643.1 from Mudigere; 0.2\% genetically divergent with the sequence AB530644.1 from Mudigere; $0.7 \%$ genetically divergent with the sequence JQ898086.1 from Gujarat; 1.4\% genetically divergent with the sequence KT991343.1 from Andaman Islands and $9.0 \%$ genetically divergent with the sequence EU071741.1 from India.

The small genetic divergence of the sequence KT991343.1 from Andaman Islands, raises the possibility of a new taxon of Duttaphrynus which could be explored with both morphological and other integrated taxonomic approaches. The large genetic divergence $(9.0 \%)$ of the sequence EU071741.1 from India needs further analysis too (Table 2).

Morphological descriptions from our specimens from Maharashtra, Karnataka and Tamil Nadu closely match the original description of D. scaber by Schneider (1799), and subsequent reports by Padhye et al. (2013); Srinivasalu et al. (2013) and Ganesh et al. (2020) from peninsular India (Fig. 1).

The metric data generated in the present study were within the range of collections made from Supdahad, Gujarat, Thrissur, and Kerala by Padhye et al. (2013). No morphological variations were documented which could create confusion in the identification of the species (Figs. 2, 5, 6 and 7).

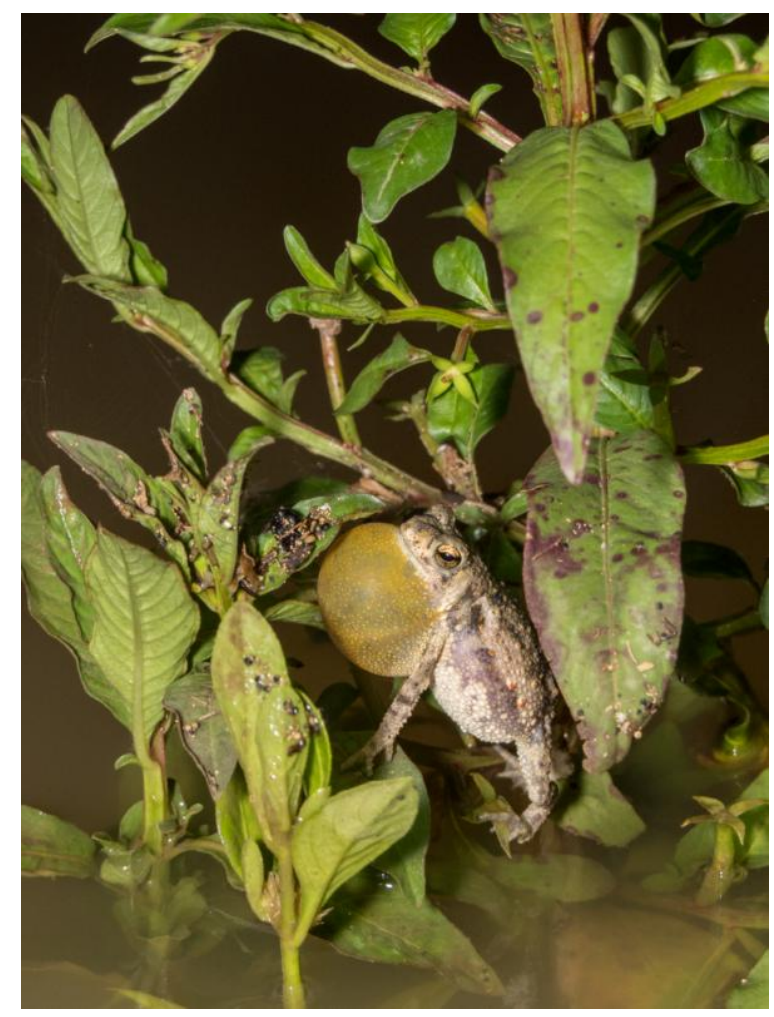

Figure 2: Adult male of Duttaphrynus scaber from Amravati, Maharashtra, India, advertising in microhabitat.

Earlier distribution records for D. scaber were from Andhra Pradesh (Srinivaslu et al., 2007), Gujarat (Padhye et al., 2013; Patel et al., 2018), Karnataka (Daniel, 1963a; Krishnamurthy, 1999), Kerala (Boulenger, 1892; Daniels, 2005), Manipur (Mathew and Sen, 2009), Odisha (Dutta, 1988; Dutta et al., 1999), Tamil Nadu (Rao, 1915; Vijayakumar, 2002), Telangana (Donahue and Daniel, 1966); western parts in Maharashtra (Padhye et al., 2013; Modak et al., 2013) and Madhya Pradesh (Prasad et al., 2020), states of India (Fig. 1, and Table 1).

The present study of $D$. scaber from Amravati is the first record of this species for Central India as well as the Vidarbha region of Maharashtra state. Earlier reports on amphibians (Chandra and Ray, 2007; Sawarkar and Kasambe, 2009, and Wagh et al., 2017) did not report this species in Central India. Amravati is located $405 \mathrm{~km}$ north of Hyderabad, Telangana, the previously closest known locality of Duttaphrynus scaber and is a range extension (Fig. 1).

Additionally, the species is also recorded from central Maharashtra (Sufiyan Nagar and Wadgaon Mahure, Amravati), the regions adjoining the states of Goa and Karnataka (Chegule, Kankumbi, Belgaum, Karnataka) and Tenkasi town (Tenkasi, Tamil Nadu) from India. 


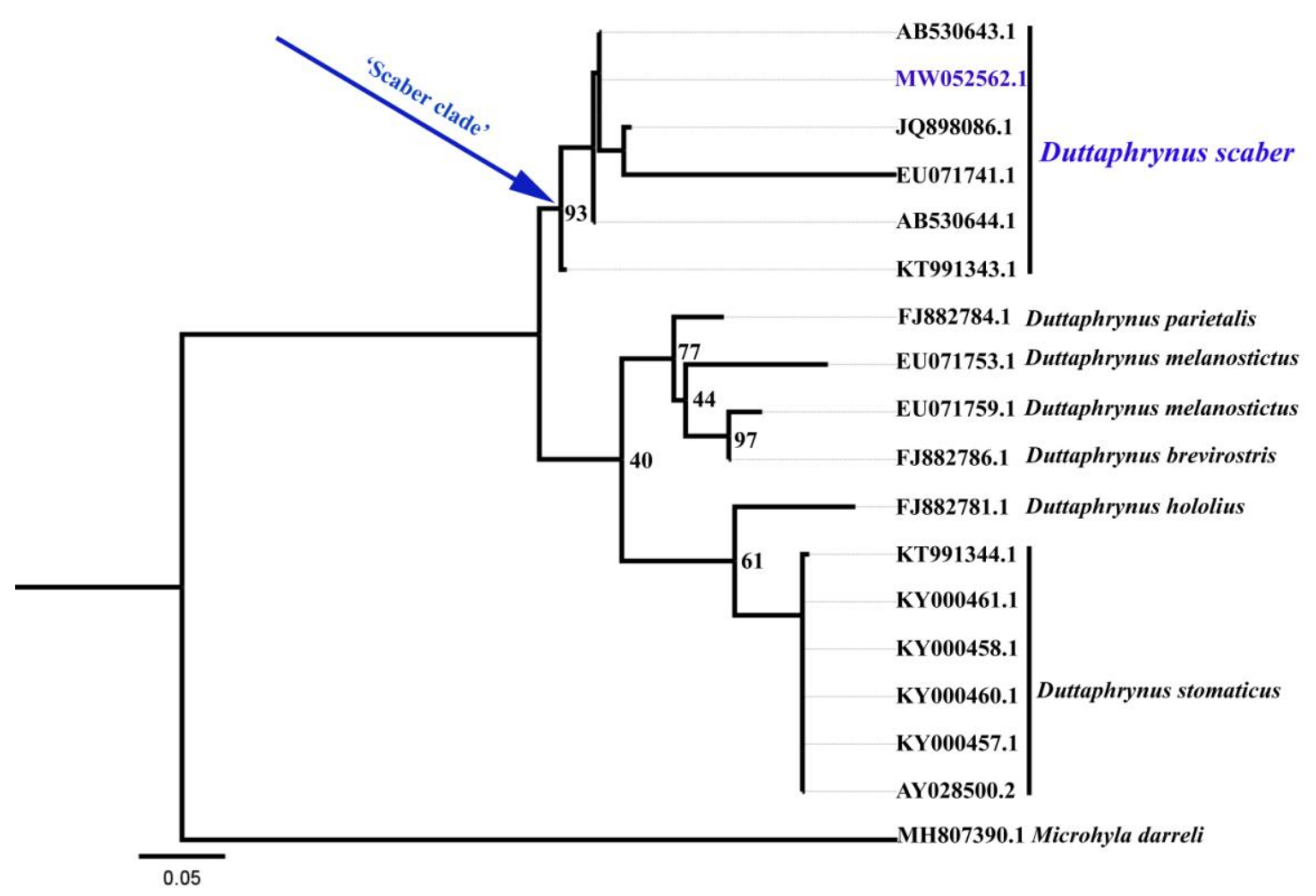

Figure 3: Maximum Likelihood tree for the members of the genus Duttaphrynus based on 531 bp of mt 16s rRNA.

Table 3: Morphometric data (to nearest $0.1 \mathrm{~mm}$ ) for Duttaphrynus scaber from India.

\begin{tabular}{|c|c|c|c|c|c|c|c|}
\hline Character & $\begin{array}{c}\text { ZSI/WRC/ } \\
\text { A/2182a }\end{array}$ & $\begin{array}{c}\text { ZSI/WRC/ } \\
\text { A/2182b }\end{array}$ & $\begin{array}{c}\text { ZSI/WRC/ } \\
\text { A/2182c }\end{array}$ & $\begin{array}{c}\text { ZSI/WRC/ } \\
\text { A/2172 }\end{array}$ & $\begin{array}{c}\text { AGCZRL } \\
41 \\
\end{array}$ & $\begin{array}{c}\text { AGCZRL } \\
42 \\
\end{array}$ & $\begin{array}{c}\text { AGCZRL } \\
98 \\
\end{array}$ \\
\hline & $\begin{array}{c}\text { Present } \\
\text { study }\end{array}$ & $\begin{array}{c}\text { Present } \\
\text { study }\end{array}$ & $\begin{array}{c}\text { Present } \\
\text { study }\end{array}$ & $\begin{array}{c}\text { Present } \\
\text { study }\end{array}$ & $\begin{array}{l}\text { Padhye et } \\
\text { al. (2013) }\end{array}$ & $\begin{array}{l}\text { Padhye et } \\
\text { al. (2013) }\end{array}$ & $\begin{array}{l}\text { Padhye et } \\
\text { al. (2013) }\end{array}$ \\
\hline Sex & Male & Male & Male & Male & Male & Male & Female \\
\hline SVL & 26.1 & 26.6 & 28.7 & 32.0 & 24.2 & 25.5 & 36.0 \\
\hline HW & 9.2 & 9.5 & 10.7 & 11.2 & 8.5 & 8.8 & 12.8 \\
\hline HL & 9.0 & 9.2 & 8.7 & 8.1 & 7.4 & 7.8 & 11.8 \\
\hline IN & 1.7 & 1.9 & 1.8 & 1.6 & 1.5 & 2.0 & 3.2 \\
\hline NE & 1.8 & 1.2 & 2.0 & 2.3 & 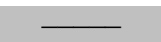 & 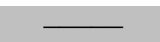 & $\underline{-}$ \\
\hline MN & 6.9 & 7.6 & 7.1 & 7.3 & 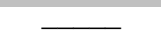 & 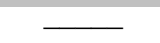 & - \\
\hline MFE & 5.9 & 6.2 & 6.0 & 5.9 & $\overline{-}$ & $\overline{-}$ & $\overline{-}$ \\
\hline MBE & 2.3 & 3.6 & 3.1 & 3.4 & $\longrightarrow$ & $\overline{-}$ & 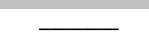 \\
\hline SL & 2.7 & 2.9 & 3.0 & 3.5 & 0.9 & 1.1 & 1.7 \\
\hline $\mathbf{E L}$ & 2.9 & 3.2 & 3.3 & 3.6 & 2.6 & 2.8 & 3.8 \\
\hline IUE & 2.2 & 2.3 & 2.3 & 3.1 & 2.7 & 2.9 & 3.4 \\
\hline UEW & 2.6 & 2.7 & 2.9 & 3.1 & 1.8 & 2.3 & 3.1 \\
\hline IFE & 4.5 & 4.8 & 4.4 & 6.0 & 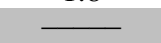 & 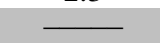 & - \\
\hline IBE & 8.3 & 8.1 & 8.7 & 9.9 & - & 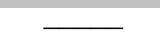 & - \\
\hline TYD & 1.6 & 1.5 & 1.3 & 2.0 & 1.0 & 1.1 & 2.6 \\
\hline TE & 0.4 & 0.3 & 0.4 & Nil & 0.8 & 0.9 & 0.3 \\
\hline FLL & 6.7 & 6.2 & 6.8 & 7.1 & $\longrightarrow$ & $\bar{\square}$ & 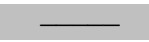 \\
\hline HAL & 6.3 & 5.4 & 5.7 & 7.2 & 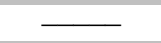 & 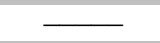 & $\longrightarrow$ \\
\hline FL1 & 1.9 & 1.8 & 2.0 & 3.0 & 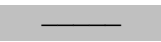 & $\bar{\square}$ & 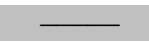 \\
\hline FL2 & 2.5 & 2.4 & 2.7 & 3.1 & $\longrightarrow$ & $\longrightarrow$ & $\longrightarrow$ \\
\hline TFL & 3.5 & 4.3 & 4.7 & 4.6 & $\underline{-}$ & 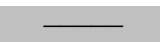 & 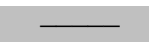 \\
\hline AGL & 12.3 & 13.1 & 14.4 & 11.5 & - & - & $\longrightarrow$ \\
\hline WBS & 10.9 & 11.4 & 12.3 & 11.6 & $\overline{-}$ & 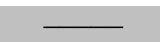 & 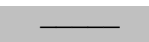 \\
\hline WFG & 13.0 & 11.7 & 12.8 & 10.2 & $\longrightarrow$ & $\longrightarrow$ & - \\
\hline ShL/ FL & 9.7 & 8.3 & 9.1 & 12.4 & 6.6 & 7.0 & 11.7 \\
\hline TiL & 9.5 & 9.6 & 9.9 & 11.5 & 8.4 & 8.5 & 11.6 \\
\hline Tal & 6.1 & 5.7 & 6.1 & 7.7 & $\underline{-}$ & $\overline{-}$ & 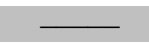 \\
\hline FOL & 10.0 & 6.8 & 8.1 & 12.5 & 13.1 & 13.7 & 18.3 \\
\hline FTL & 5.2 & 3.8 & 4.4 & 6.6 & 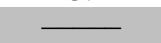 & 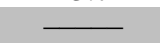 & $\underline{-}$ \\
\hline ITL & 1.6 & 1.5 & 1.7 & $\longrightarrow$ & - & 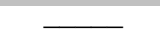 & 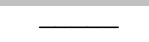 \\
\hline IMT & 0.8 & 0.8 & 1.0 & 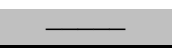 & 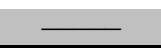 & $\overline{-}$ & $\bar{\square}$ \\
\hline
\end{tabular}


During active periods, the toads were found to be abundant after dark, in lentic water bodies around Wadgaon Mahure (Fig. 4) and the Pohra-Malkhed Reserved Forest (PMRF), within semi-arid and scrub forests and degraded dry and deciduous forests. Males are comparatively more vocal after first rains, particularly after dusk. One female specimen (Fig. 5) was observed emerging from refuge inside a termite mound. Another individual (Fig. 6) shows unusual yellowish colors, here interpreted as a partially xanthochromatic individual.

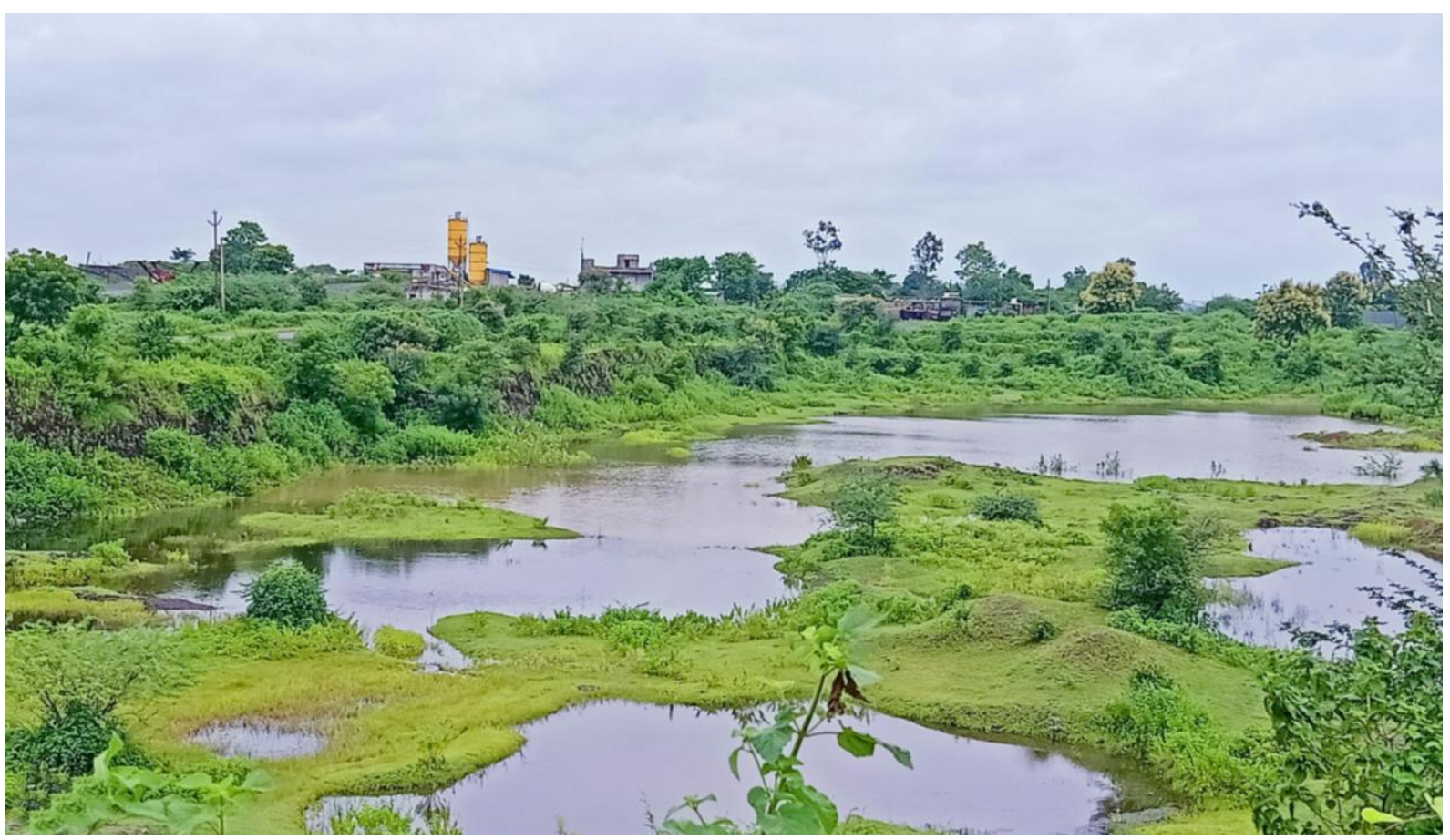

Figure 4: Habitat view of collection site of Duttaphrynus scaber in Wadgaon Mahure, India.

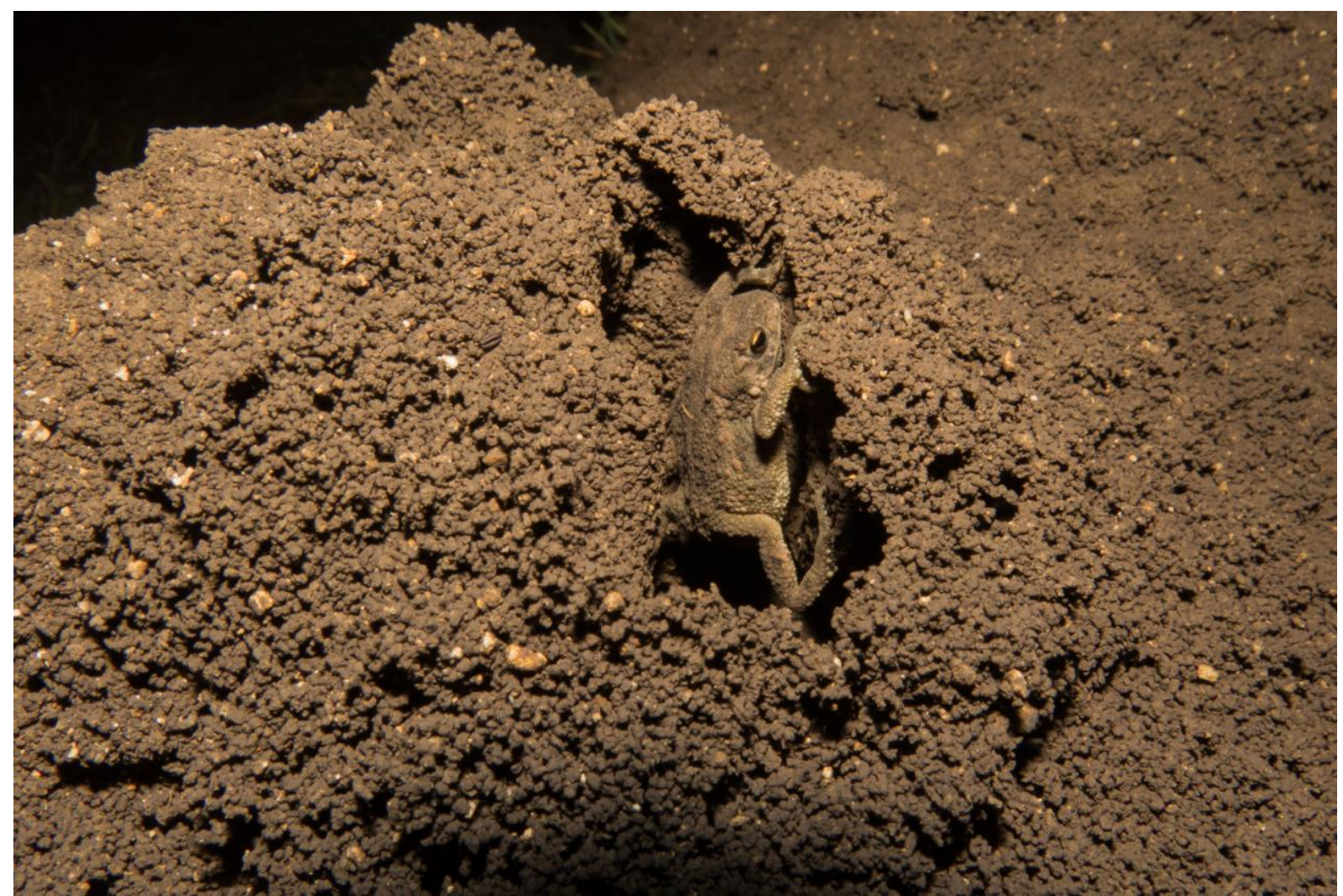

Figure 5: Female of Duttaphrynus scaber (not collected) during emergence from brumation from Amravati, Maharashtra, India. 


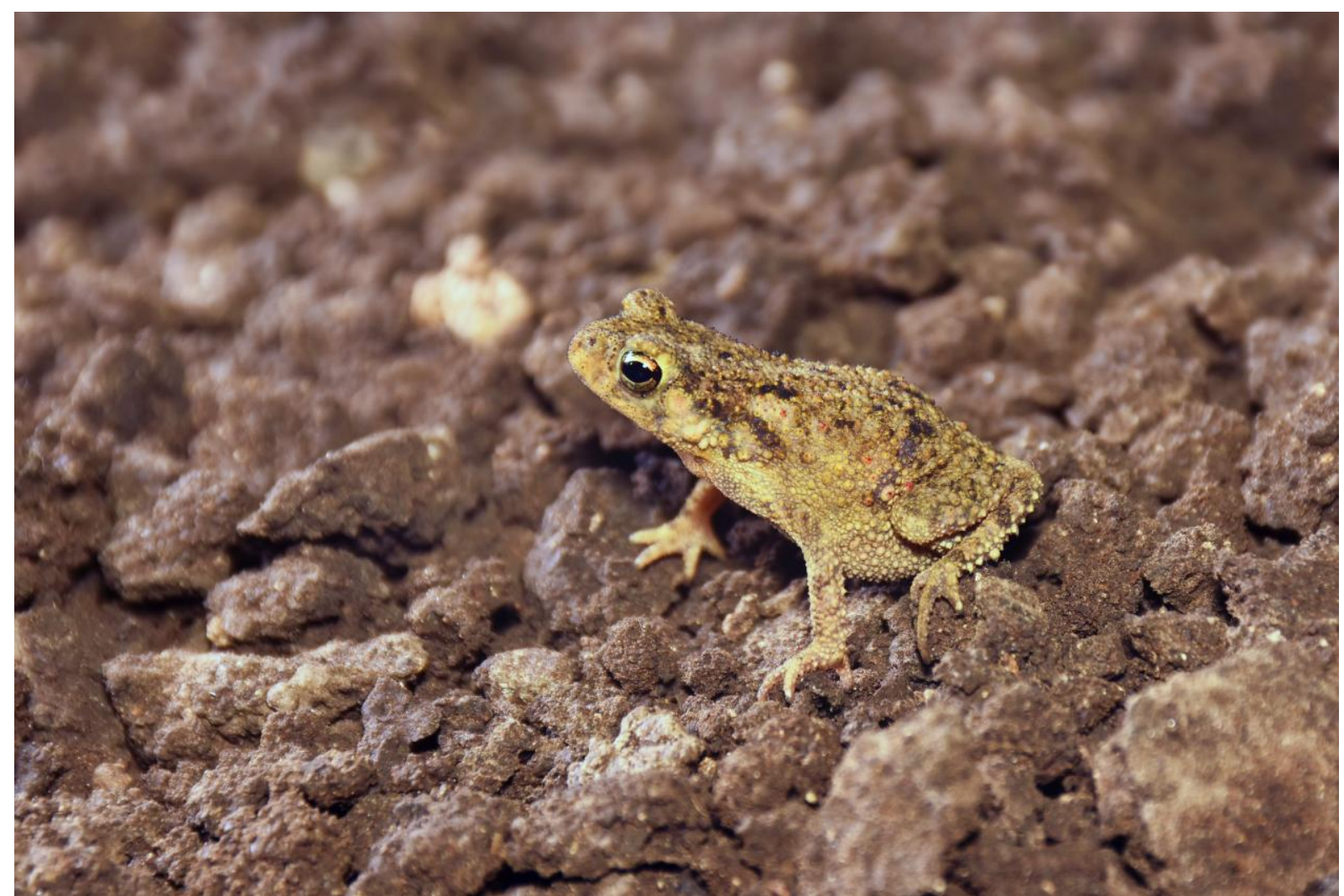

Figure 6: An adult xanthochromatic individual of Duttaphrynus scaber from Amravati, Maharashtra, India.

The specimen collected at Chegule village (Fig. 7) was calling at $1900 \mathrm{hrs}$ from a temporary muddy pool surrounded by agricultural land, during the month of July 2014 , which is the peak monsoon period in the area.
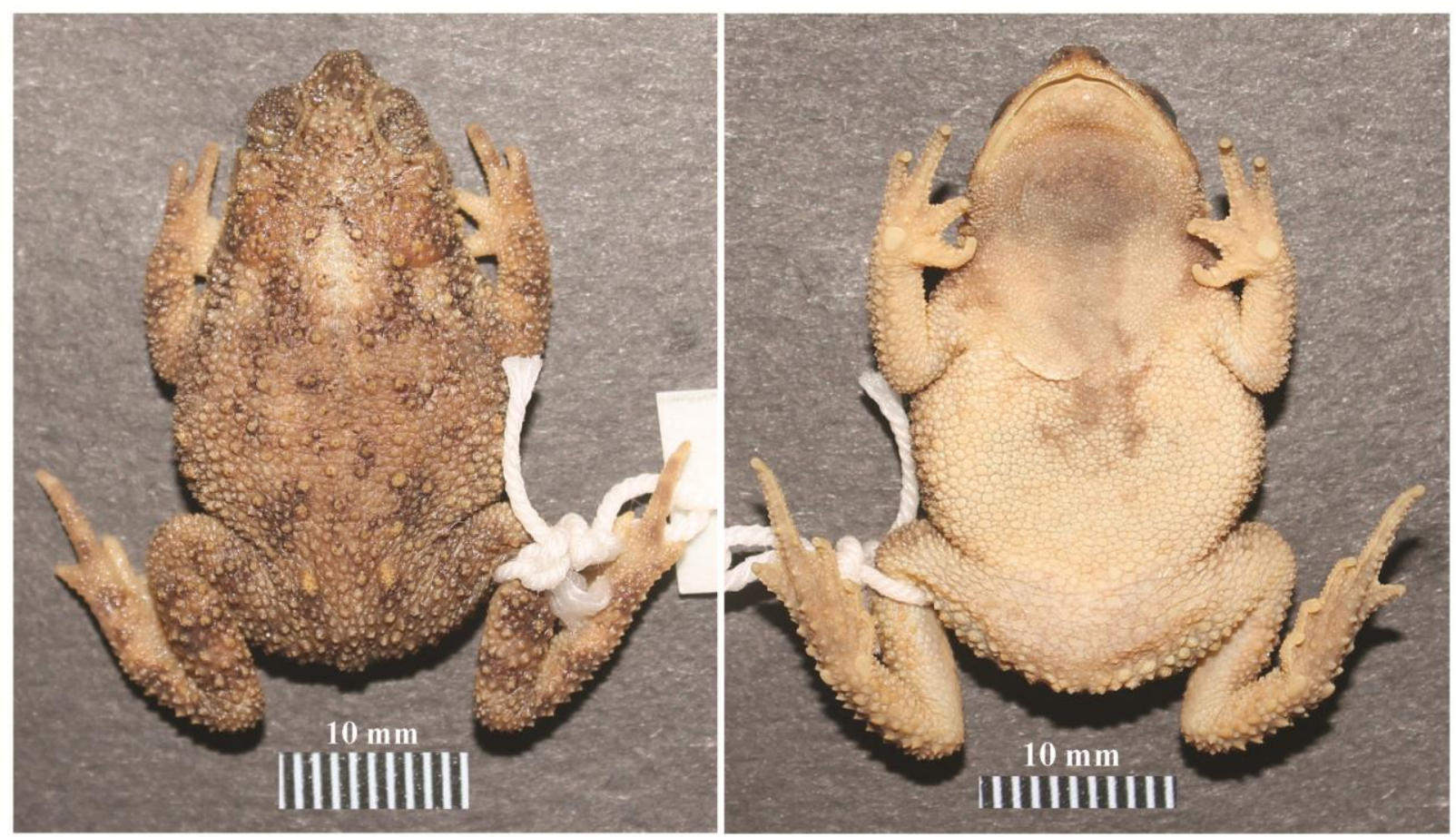

Figure 7: Duttaphrynus scaber (ZSI/WRC/A/2172) in the National Zoological Collections of ZSI, WRC, Pune, India. 
Other sympatric amphibian species calling were Microhyla nilphamariensis Howlader, Nair, Gopalan, and Merilä, Minervarya gomantaki (Dinesh, Vijayakumar, Channakeshavamurthy, Torsekar, Kulkarni, and Shanker), Minervarya syhadrensis (Annandale), Hoplobatrachus tigerinus (Daudin) and Polypedates maculatus (Gray). Male individuals were found to call from emergent leaves of bushes submerged in the muddy pools.

Individuals sighted at Tenkasi town were found calling around $19 \mathrm{hrs}$ in the stagnant paddy fields during August, as these areas fall within the rain shadow region bordering the Western Ghats. Other sympatric amphibian species calling with $D$. scaber were Minervarya agricola, M. syhadrensis and Hoplobatrachus tigerinus.

Barve and Chaboo (2011) reported ectoparasitic larvae of chlaeniines beetles of the family Carabidae infesting D. scaber in April 2008 near Karanji Lake, within the campus of the Regional Museum of Natural History, Mysore, Karnataka, India. Habitat loss, especially due to anthropogenic activities and developmental projects, including mining is a potential threat to the species.

Further population level studies, based on extensive field surveys, are warranted to understand the distribution and the threats this species is facing. Other studies include the effects of water contamination, developmental deformities, natural history and population status of $D$. scaber in central India.

\section{Acknowledgements}

Part of this publication is an outcome of the Open Taxonomy Initiative, supported by Kartik Shanker and Seenapuram Palaniswamy Vijayakumar at the Evolutionary Ecology Lab, Centre for Ecological Sciences (CES), Indian Institute of Science (IISc), Bangalore. KPD would like to thank the Department of Biotechnology, Government of India and Science and Engineering Research Board (SR/FR/LS88/210/09.05.2012) for a fellowship and financial assistance to conduct part of this work, and is grateful to the Director of the Zoological Survey of India (ZSI), Kolkata and the Officer-in-Charge, ZSI, WRC, Pune for encouragement. NUK is thankful to the Trustees of Mhadei Research Centre (MRC) for their continuous support. The authors also thank Saipari Sailo, Ahsan Sheikh, Yadav Tarte, Sawan Deshmukh and Vaibhav Dalal for their contributions to the field survey and Harshil Patel, for his support in the study. KA extends gratitude to Cuckoo Mahapatra (Department of Zoology, North Orissa University, Mayurbhanj, Odisha) for laboratory support and her comments during manuscript preparation. Our thanks also go to Indraneil Das (University Malaysia Sarawak, Malaysia) and the anonymous reviewers for their valuable comments and corrections on the manuscript.

\section{Conflict of interest}

All the authors declare that there are no conflicting issues related to this research article.

\section{References}

Barve, V. V. and Chabo, C. S. (2011). Duttaphrynus scaber (Ferguson's Toad). Predation by beetles. Herpetological Review, 42 (1): 83-84.

Bocxlaer, V, I., Biju, S. D., Loader, S. P. and Bossuyt, F. (2009). Toad radiation reveals into-India dispersal as a source of endemism in the Western Ghats-Sri Lanka biodiversity hotspot. BMC Evolutionary Biology, 9, 131. https://doi.org/10.1186/1471-2148-9-131

Boulenger, G. A. (1892). Description of a new toad from Travancore. Journal of the Bombay Natural History Society, 7: 317-318.

Chandra, P. K. and Ray, S. (2007). Fauna of Madhya Pradesh including Chhattisgarh. State fauna series No. 15, Part-1 Published by Zoological Survey of India. $1-564$.

Chandramouli, S. R., Vasudevan, K., Harikrishnan, S., Dutta, S. K., Janani, S. J., Sharma, R., Das, I. and Aggarwal, R. K. (2016). A new genus and species of arboreal toad with phytotelmonous larvae, from the Andaman Islands, India (Lissamphibia, Anura, Bufonidae). Zookeys, 555: 57-90. https://doi.org/10.3897/zookeys.555.6522

Daniel, J. C. (1963a). Field guide to the amphibians of western India. Part I. Journal of the Bombay Natural History Society, 60 (2): 415-438.

Daniel, J. C. (1963b). Field guide to the amphibians of western India. Part II. Journal of the Bombay Natural History Society, 60 (3): 690-702.

Das, I. and Martin, G. (1998). Bufo fergusonii (Ferguson's Toad). Ecology. Herpetological Review, 29 (3): 164.

Donahue, J. P. and Daniel, J. C. (1966). Occurrence of the toad Bufo fergusonii Boulenger in Hyderabad, Andhra Pradesh, India (Anura: Bufonidae). Journal of the Bombay Natural History Society, 63: 447.

Dubois, A. and Ohler, A. (1999). Asian and oriental toads of the Bufo melanostictus, Bufo scaber and Bufo stejnegeri groups (Amphibia, Anura): a list of available and valid names and redescription of some name-bearing types. Journal of the South Asian Natural History, 4: 133-180.

Dutta, S. K. (1988). First records of Bufo stomaticus and Bufo fergusonii (Anura: Bufonidae) from Orissa, with comments on their distribution. Journal of the Bombay Natural History Society, 63 (2): 439-441.

Dutta, S. K. (1997). Amphibians of India and Sri Lanka. Odyssey Publishing House, Bhubneshwar. $132 \mathrm{pp}$. 
Dutta, S. K., Nair, M. V., Mohapatra, P. P. and Mahapatra, A. K. (2009). Amphibians and reptiles of Similipal Biosphere Reserve. Regional Plant Resource Centre, Bhubaneswar, Orissa, India. 174 pp. https://doi.org/10.13140/2.1.2440.0647

Frost, D. R. (2020). Amphibian Species of the World: An Online Reference. Version 6.1. Electronic Database (accessed on 07/11/2020) at https://amphibiansoftheworld.amnh.org/index.php - American Museum of Natural History, New York, USA. https://doi.org/10.5531/db.vz.0001

Ganesh, S. R., Rameshwaran, M., Joseph, N. A., Jerith, A. M. and Dutta, S. K. (2020). Records of two toads Duttaphrynus scaber and D. stomaticus (Amphibia: Anura: Bufonidae) from southeastern India. Journal of Threatened Taxa, 12 (10): 16272-16278.

https://doi.org/10.11609/jott.6110.12.10.1627216278

Hasan, M., Islam, M. M., Khan, M. R., Igawa, T., Alam, M. S., Djong, H. T., Kurniawan, N., Joshy, H., Sen, Y. H., Belabut, D. M., Kurabayashi, A., Kuramoto, M. and Sumida, M. (2014). Genetic divergences of South and Southeast Asian frogs: a case study of several taxa based on $16 \mathrm{~S}$ ribosomal RNA gene data with notes on the generic name Fejervarya. Turkish Journal of Zoology, 38 (4): 389-411.

IUCN (2020). The IUCN Red List of Threatened Species 2004: e.T54753A11199889. https://dx.doi.org/10.2305/IUCN.UK.2004.RLTS. T54753A11199889.en. Downloaded on 08 November 2020.

Krishnamurthy, S. V. (1999). Amphibian diversity in a few selected environs of Western Ghats, In: Hussain, S. A. and Achar, K. P. (Eds.), Biodiversity of the Western Ghats complex of Karnataka, Biodiversity Initiative Trusts, Mangalore, India. pp. 107-117.

Mahapatra, A. D. and Ghorai, S. K. (2019). New record of Duttaphrynus scaber (Schneider, 1799), the Schneider's Toad (Family: Bufonidae) from West Bengal, India. Biological Forum - An International Journal, 11 (2): 56-60.

Mathew, R. and Sen, N. (2009). Studies on little known amphibian species of North East India. Records of the Zoological Survey of India, Occasional Paper, Volume, 293. Director, Zoological Survey of India, Kolkata. 64 pp +23 plates.

Modak, N., Padhye, A. and Bayani, A. (2013). A report of Duttaphrynus scaber Schneider (1799) (Anura: Bufonidae), with abnormal toes, from Gavase, Kolhapur District, Maharashtra. Ela Journal of Forestry and Wildlife, 2 (3): 2-6.
Padhye, A., Pandit, R., Patil, R., Gaikwad, S., Dahanukar, N. and Shouche, Y. (2013). Range extension of Ferguson's Toad Duttaphrynus scaber (Schneider, 1799) (Amphibia: Anura: Bufonidae) up to the northern most limit of Western Ghats, with its advertisement call analysis. Journal of Threatened Taxa, 5 (11): 4579-4585.

Patel, H., Vyas, R., Naik, V., Dudhatra, B. and Tank, S. K. (2018). Herpetofauna of the Northern Western Ghats of Gujarat, India. Zoology and Ecology, 28 (3): 213-223. https://doi.org/10.1080/21658005.2018.1499237

Pramuk, J. B., Hass, C. A. and Hedges, S. B. (2001). Molecular phylogeny and biogeography of West Indian toads (Anura: Bufonidae). Molecular Phylogenetics and Evolution, 20 (2): 294-301. https://doi.org/10.1006/mpev.2001.0985

Prasad, V. K., Das, A. and Gautam, K. (2020). Identification of anuran species diversity of the Panna Tiger Reserve, Central India, using an integrated approach. Zootaxa, 4851 (3): 450-476. https://doi.org/10.11646/zootaxa.4851.3.2

Rao, C. R. N. (1915). Notes on some south Indian Batrachia. Records of Indian Museum, 11: 31-38.

Sawarkar, D. B. and Kasambe, R. (2009). A survey of the amphibian fauna of Nagpur, Maharashtra. Bionotes, 11 (3): 84-85.

Schneider, J. G. (1799). Historiae Amphibiorum Naturalis et literariae. Fasciculus Primus. Continens Ranas, Calamitas, Bufones, Salamandras et Hydros in Genera et Species Descriptos Notisque suis Distinctos. Jena, Friederici Frommanni. 264 pp.

Srinivaslu, C., Siliwal, M., Rajesh, A., Srinivasulu, B., Venkateshwarulu, P. and Nagulu, V. (2007). Diversity and distribution of amphibian fauna in Nagarjunasagar-Srisailam Tiger Reserve, Andhra Pradesh. Frogleg, 13: 3-6.

Srinivasulu, B., Ganesh, S. R. and Srinivasulu, C. (2013). New regional record and notes on historical specimens of Günther's Toad Duttaphrynus hololius with comments on other southeastern Indian congeners. Journal of Threatened Taxa, 5 (13): 4784-4790. https://doi.org/10.11609/JoTT.o3621.4784-90

Vijayakumar, S. P. (2002). On the occurrence of Bufo scaber Schneider, 1799 from Kalakkad Mudanthurai Tiger Reserve, Tamil Nadu. Frogleg, 10: 2-3.

Wagh, G. A., Rawankar, A. S., Sharma, V. and Wadatkar, J. S. (2017). A preliminary study on the amphibian diversity in different habitats of Amravati district, Maharashtra. Journal of Entomology and Zoology Studies, 5 (1): 158-162. 